\title{
Primerjava govorov Babnega Polja in Ravnic v luči starejših in mlajših slovenskih jezikovnih sprememb
}

\author{
Januška Gostenčnik
}

Cobiss: 1.01

\begin{abstract}
Prispevek predstavlja primerjavo govorov krajev Babno Polje, ki spada v kostelsko narečje dolenjske narečne skupine, in Ravnice v Gorskem kotarju na Hrvaškem. Oba govora sta vključena v mrežo Slovenskega lingvističnega atlasa (SLA). Diahrona primerjava obeh govorov na fonološki ravnini kaže na njuno skupno lingvogenezo, s čimer se utemeljuje vključitev govora Ravnic v regularno mrežo SLA. Govor Ravnic je na osnovi mlajših jezikovnih pojavov uvrščen v kostelsko narečje.
\end{abstract}

Ključne besede: dialektologija, Slovenski lingvistični atlas, kostelsko narečje, dolenjska narečna skupina, fonologija

\section{A comparison of the local dialects of Babno Polje and Ravnice in the light of older and more recent Slovene language phenomena}

This article compares the local dialects of Babno Polje in Slovenia and Ravnice in Croatia's Gorski Kotar region. Both local dialects are part of the data-point network for the Slovenski lingvistični atlas (Slovenian Linguistic Atlas, SLA). A diachronic comparison of both local dialects at the phonological level shows their common linguistic genesis and thus justifies inclusion of the local dialect of Ravnice within a regular data-point network for the SLA. The local dialect of Ravnice is classified as part of the Kostel dialect based on more recent language phenomena.

Key words: dialectology, Slovenian Linguistic Atlas, Kostel dialect, Lower Carniolan group, phonology

\section{Uvod}

Krajevni govor ${ }^{1}$ Babnega Polja $^{2}$ (SLA T279) se od izida Slovenskih narečij (1975) dialektologa Tineta Logarja dalje uvršča med kostelske govore dolenjske narečne

1 Prispevek je nastal v okviru aplikativnega raziskovalnega projekta ARRS in SAZU L6-4042 Materialna kulturna dediščina v slovenskih narečjih: geolingvistična predstavitev, ki ga vodi Jožica Škofic. - Za pregled prispevka in za vse pripombe se zahvaljujem dr. Jožici Škofic.

2 Gradivo za krajevni govor Babnega Polja sem črpala iz zapisa za SLA Albince Lipovec, ki se hrani v Dialektološki sekciji Inštituta za slovenski jezik Frana Ramovša ZRC SAZU 
- $\quad$ skupine, ${ }^{3}$ diahrono gledano pa spada med južna slovenska narečja, torej je del do[그 lenjske narečne ploskve (Šekli 2009: 294).

Krajevni govor Ravnic ${ }^{4}$ na Hrvaškem - kontrolna točka SLA T411 (SLA 1.2: 22) - hrvaška dialektologija uvršča med gorskokotarske govore oz. v zahodno goransko narečje kajkavske narečne skupine hrvaškega jezika (hrv. zapadnogoranski poddijalekt goranskog dijalekta kajkavskog narječja). O utemeljenosti te uvrstitve govorim v tem prispevku. Krajevni govor Ravnic namreč ne izkazuje tipičnih kajkavskih definicijskih lastnosti. Veliko laže pa ga zato povežemo z bližnjim slovenskim krajevnim govorom Babnega Polja z dolenjsko osnovo.

$\mathrm{V}$ obeh krajevnih govorih sta relevantna le mesto naglasa in kvantiteta. Izkazane so kvantitetne opozicije v naglašenih zlogih.

\section{$2 \quad$ Kajkavske definicijske lastnosti}

Kajkavska narečna skupina pozna dve skupini govorov (Lončarić 1982; 1996), in sicer t. i. glavnino narečij (sem se prištevajo kajkavski govori, ki izkazujejo vse »glavne« oz. tipične kajkavske značilnosti) in obrobni, manjši del narečij, kjer govori ne izkazujejo vseh tipičnih kajkavskih značilnosti - sem se prištevajo tudi t. i. goranski govori.

Tipične kajkavske značilnosti, ki jih izkazuje večina narečij v kajkavski narečni skupini, najdemo znotraj prozodije in vokalizma. ${ }^{5} \mathrm{Z}$ osnovno kajkavsko akcentuacijo (po Ivšić 1936) se kajkavska narečna skupina od 10. stoletja dalje jasno loči od sosednjih jezikovnih sistemov (Lončarić 1996: 23). V vokalizmu so za kajkavska narečja značilni naslednji sovpadi: zjsl. *ě in *a ter zjsl. * $Q$ in *l (Ivić 1961; Lončarić 1996; Šekli 2013: 12). V goranskih govorih prihaja do izostanka vseh omenjenih glavnih kajkavskih značilnosti.

v Ljubljani, in iz lastnega terenskega dela, opravljenega v letih 2010-2011. Fonološki opis krajevnega govora Babnega Polja je objavljen v Lipovec - Benedik 1981: 119, dopolnjen pa predstavljen v Gostenčnik 2013: 66.

3 Fran Ramovš je govor Babnega Polja razlikoval od bolj južnih kostelskih govorov - te je prištel $\mathrm{k}$ belokranjskemu narečju $\mathrm{z}$ dolenjsko narečno osnovo - in ga uvrstil k zahodnemu dolenjskemu narečju (Ramovš 1931). Vendar pa se predvideva, da Ramovš govorov na severozahodnem delu ni poznal najbolje. Zapis za SLA (in Slovanski lingvistični atlas - OLA), ki ga je leta 1966 za govor kraja Babno Polje pripravila Albinca Lipovec, je nedvomno pripomogel k poznavanju tega govora. Neposredna posledica tega je bila sprememba narečne meje na karti slovenskih narečij Tineta Logarja in Jakoba Riglerja iz leta 1986.

4 Gradivo za krajevni govor Ravnic, predstavljeno $\mathrm{v}$ tem prispevku, sem zbrala sama $\mathrm{s}$ terenskim delom v letih 2010-2013 (natančnejši podatki o informatorju so navedeni v Gostenčnik 2013: 267). Ponekod je dopolnjeno z gradivom, zbranim za SLA. Fonološki opis krajevnega govora Ravnic je predstavljen v moji doktorski disertaciji (Gostenčnik 2013: 82).

5 Soglasniško merilo (Belić 1927; Brozović 1960; Lončarić 1996), tj. refleksi psl. *t in *d, ki prav tako služi za klasifikacijo kajkavskih govorov, na tem mestu ni omenjeno, saj Belić pri svoji znanstveni delitvi kajkavskih narečij goranskih govorov ni upošteval. 


\subsection{Sovpad odrazov za zjsl. *ě in *o}

Govor kraja Ravnice ne izkazuje omenjene kajkavske definicijske lastnosti. Odrazi zjsl. *̌ in *a so v govorih Ravnic in Babnega Polja večinoma enaki (z izjemo ohranjene labializacije v govoru Babnega Polja).

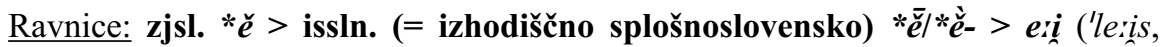

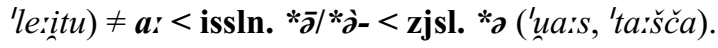

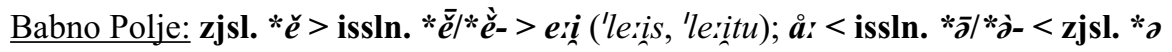
('våss, 'tå:šča).

\subsection{Sovpad odrazov zjsl. * $\boldsymbol{Q}$ in * $l$}

Govor kraja Ravnice ne izkazuje te kajkavske definicijske lastnosti. Tako refleks govora Ravnic kot Babnega Polja je mogoče izvajati iz dolenjskega *uo, govor Ravnic pa že izkazuje sekundarno monoftongizacijo.

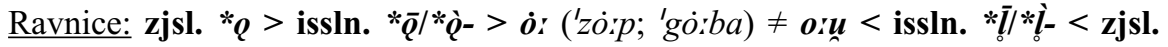
${ }^{*} \boldsymbol{C b l C},{ }^{*} \boldsymbol{C b l C},{ }^{*} \mathrm{ClbC},{ }^{*} \mathrm{ClbC},{ }^{*} \mathrm{CelC},{ }^{*} \mathrm{ColC}-$ 'uoruk 'volk', 'po:ut 'polt', 'žo'una, 'so:uza, 'bo:uxa; 'uo:una 'volna', prid. ž. 'do:uga.

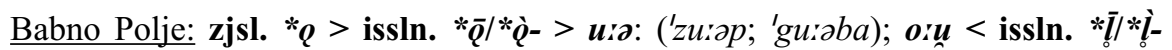

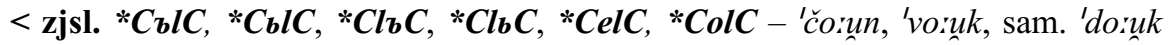
'dolg', 'bo:uxa, 'žo:una, 1. os. ed. sed.: 'mo:uzen 'molsti', 'do:ưben 'dolbsti'; 'vo:una, im. mn. 'po:uxi, prid. ž.: 'do:uga, 'po:una.

\section{Splošnoslovenske inovacije}

Splošnoslovenske inovacije so slovenski jezikovni sistem zamejile od preostale zahodne južne slovanščine. Kronološko gledano je prva inovacija pomik naglasa tipa starega cirkumfleksa na naslednji zlog v večzložnicah, tj. progresivna metataksa cirkumfleksa. Sledi mu premik naglasa s končnega kratkega zloga na predhodni dolgi praslovanski samoglasnik, tj. umik na prednaglasno dolžino.

3.1 Splošnoslovenski pomik cirkumfleksa oz. splošnoslovenska progresivna metataksa cirkumfleksa

V govorih Babnega Polja in Ravnic je v nadaljnjem razvoju prišlo do terciarnega premika cirkumfleksa, ${ }^{6}$ kar dokazujeta tako kvantiteta, tj. kračina novonaglašenega vokala, kot kvaliteta, tj. redukcijska barva vokala.

Babno Polje: 'vixar, 'jẹmi 'ime', d'revu, 'kakuš, 'kauo, 'galop 'golob', 'abərf 'obrv', 'sorci 'srce', 'uaku 'oko', 'čẹu 'črevo'; 'mesu, 'testu, 'teuo, 'nebu, 'peru, 'sẹnu, rod. ed.: 'vasi 'vas', 'vẹ̌si 'uš', 'pesti 'pest', 'zaba 'zob', 'maža 'mož', 'raba 'rob', k'lapi 'klop',

\footnotetext{
6 Tako tudi v vseh drugih govorih kostelskega narečja.
} 
- $\quad$ 'peti 'peta', 'peči, s'veta, 'lesa, d'uani, 'vaza 'voz', 'nači, 'raga 'rog', 'baga 'bog', 'mači

표 'moč', 'nagi 'noga', im. mn.: 'uasi 'las', 'uači, 'zabi, 'naxti, del. na. -lm. 'abriu 'obriti', prid. m. 'bauan 'bolan', 'lẹpu, z'večẹr, 'taku, 'devẹt, 'desẹt, 'dẹšit 'dišati', 'sẹšit 'sušiti'.

Ravnice: 'mesu, 'nebu, 'peru, 'pepiu, 'večir (̌̌.), 'kakuš, 'gauop 'golob', 'kaun, 'sərci, 'senu, 'tesstu, rod. ed.: p'raxa, v'rata, st'rani, 'nači, 'mači 'moč', 'nagi, 'baga 'bog', 'kasti, 'uasi 'vas', 'maža, 'zaba 'zob', 'raba, 'kapi 'klop', 'lesa, s'nega, s'mexa, z'veri, 'peči, 'meda (star.) 'mé:da (nov.) - po analogiji na im. ed. 'mé:t 'med', 'leda (star.) 'lè:da (nov.) - po analogiji na im. ed. 'lè:t 'led', 'pesti, im. mn. g'radi 'grad', 'zabi 'zob', prid. m. 'bauen 'bolan', 'lepu, 'devit '9', 'desit '10'.

\subsection{Splošnoslovenski umik naglasa s končnega zloga na prednaglasno dolži- no se odraža kot dolžina pod naglasom.}

Babno Polje: m'le:iku, z've:izda, s've:ičca, b'rå:da, t'råvva, g'uåarva, 'mu:'ka 'moka'.

Ravnice: m'le:inu, g'ne:izdu, z've:izda, s'te:ina, t'ra:ua, g'ua:una g'uo:ua, v'ra:ta, 'mo:ka.

\section{$4 \quad$ Starejše jezikovne spremembe}

Enotni slovenski jezikovni sistem so načele jezikovne spremembe, ki so povzročile narečno drobitev jezikovnega sistema. To so bile najzgodnejše jezikovne spremembe (od 12. do 14. stoletja) oz. starejši jezikovni pojavi, na podlagi katerih se slovenski sistem diahrono deli na narečne ploskve oz. skupine narečij.

4.1 Zgodnja denazalizacija issln. ${ }^{*} \bar{\ell} / * \grave{e}-,{ }^{*} \overline{\boldsymbol{Q}} / * \grave{\boldsymbol{Q}}-$

Zgodnja denazalizacija je značilna za južna in vzhodna slovenska narečja, kjer imata zato nosnika ozke reflekse. Tak razvoj odražajo tudi refleksi v obeh obravnavanih govorih.

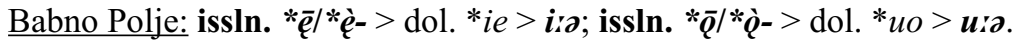

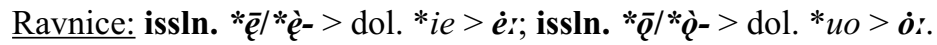

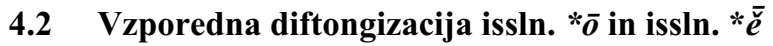

Diftongizacija issln. ${ }^{*} \bar{o}$ in issln. $* \bar{e}$ je potekala v smeri, značilni za južna in vzhodna slovenska narečja, tj. jsln. *ei in *oun. Za dolenjsko narečno ploskev pa je značilna nadaljnja monoftongizacija jsln. $*$ ou $>$ dol. $* \bar{u}$, kar izkazujeta tudi oba obravnavana govora (sicer po mlajši sekundarni krajšavi visokega vokala).

Babno Polje:

Issln. * $\overline{\boldsymbol{e}}>$ jsln. *ei > dol. *ei > exi - g're:ix, s'me:ix, s'ne:ig, 'ce:ip, 'le:is, b're:ik,

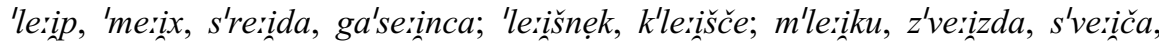


'če:îda ‘čreda', prid. ž.: 'le:inpa, 'be:ina; bẹ'se:inda, 'če:iňšna, 'me:insọ, im. mn. 'me:insta, rod. mn. 'le:it 'leto', 1. os. ed. sed. 'de:iuan 'delati'.

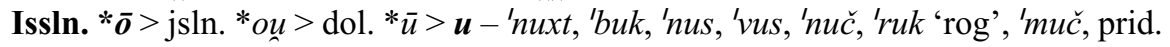
m. g'lux, z'gun, 'pulie, 'kust, im. mn. ka'kuši .

Ravnice:

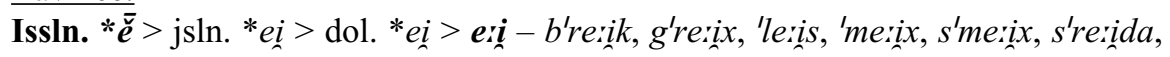
prid. m.: 'le:inp, 'le:inin; 'pe:insek, k'le:inš̌ce; prid. ž. 'be:ina m'le:inku, g'ne:indu, d'le:intu,

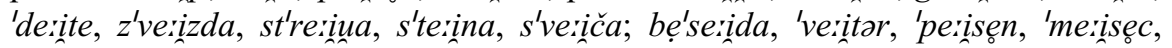
x'le:ibec, im. mn. 'me:ista, 3. os. ed. sed. 'de:illa.

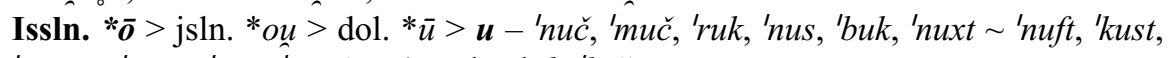
'must $\sim$ 'most, 'us 'vus 'voz', rod. ed. ka'kuši.

\subsection{Zgodnje daljšanje issln. kratkih akutiranih zložnikov $v$ nezadnjem be-} sednem zlogu je v zahodnih in južnih slovenskih narečjih razvidno v dolžini naglašenega zloga, zlasti pa v vzporednem razvoju in posledično v enakem refleksu stalno dolgega jata in kratkoakutiranega jata v nezadnjem besednem zlogu.

Babno Polje:

Issln. *à- > år - 'kå:mọn, 'jårvar, 'gå:bor, k'rårva, s'ưåma, 'rå:ma, 'må:te, 'på:met, 'se:ime, 'så:úo 'salo', rod. ed. b'rå:ta.

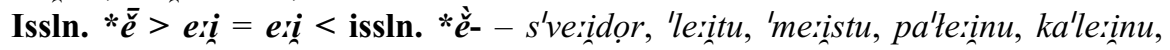
b're:iza, 'ce:ista, nẹ've:ista, st're:ixa, 'pe:inna, ne'de:inla, rod. ed. a're:ixa, pa'verîndat, 're:izat, 2. os. mn. 'verišste 'vedeti'.

\section{Ravnice:}

Issln. *à->a: - rod. ed. b'ra:ta, 'sa:uu 'salo', 'le:îtu, 'se:ime, b'ua:tu, 'pa:met, 'ra:ma, k'ra:ua, 'ža:ba, 'ba:ba, 'ma:te 'mati', 'pa:lca, s'uama, prid. ž. s'ta:ra.

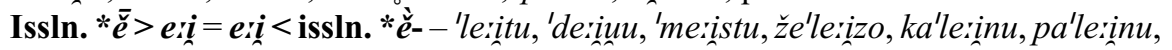
b're:iza, sm're:ina, 'ce:insta, ne've:ista, st're:inxa, 'pe:inna, 1. os. ed. sed. 've:in.im.

\subsection{Sovpad $e$-jevskih in $o$-jevskih glasov}

Za južna slovenska narečja je značilen tudi sovpad $e$-jevskih in $o$-jevskih glasov: issln. $* \bar{e} / * \grave{e}-$ in issln. $* \bar{e} / * \grave{e}-$ ter $* \grave{o}-$ in issln. $* \bar{Q} / * \grave{Q}->$ jsln. $* \bar{e}$ in $* \bar{o}$. Dalje se jsln. $*^{*} \bar{e}$ in $* \bar{o} \mathrm{v}$ dolenjski narečni ploskvi diftongirata v smeri proti $*_{i e}$ in $* u o$. Govor Babnega Polja izkazuje diftonške reflekse, v govoru Ravnic pa je že prišlo do monoftongizacije.

Babno Polje:

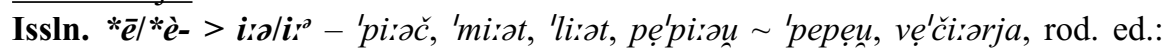

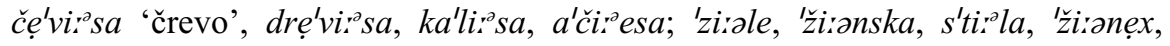
'pirarje, rod. ed.: sệ'mi: na, vrẹ'mi: na, jẹc'mi: na, tẹlirata, k'mi:ata, pag'riraba, vẹš̌i:asa 'uho', rod. mn. 'rirabọr 'rebro', prid. ž. dẹ'bi:auna, 'si:adọn '7', t'ri:atje 'tretji', 1. os. ed. sed. 'mi:ačen 'metati', del. na -l m. 'ni:asu 'nesti', 'pi:əku 'peči', 


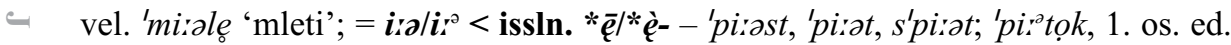
sed. 'vi:zžen 'vezati', p'li:əšen 'plesati', p'ri:aden 'presti', g'ri:zn 'iti', 3. os. ed. sed. 'zi:abe 'zebsti'; 1. os. ed. sed. g'li:adan, 3. os. ed. sed. zg'lizada; s'ri:ača, 'diratela, pak'li:aknẹt.

Issln. *ò- > uro/ur - 'du:zta 'dota', 'ku:ža, 'vu:ala, 'xu:əja 'hoja', 'nu:əša, šku:əda,

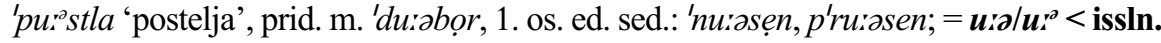

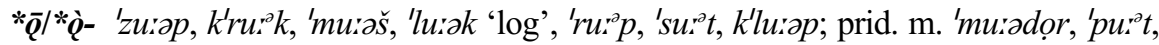

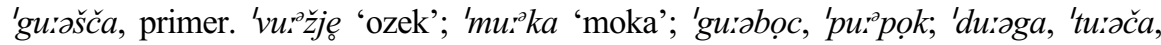
'guiaba.

Ravnice:

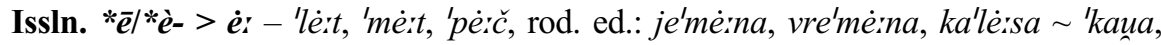
pe'réssa 'pera, '̌̌ést; 'žénska, 'stè:ua, 'žé:nix 'ženin', 'pérrje, rod. ed.: k'mé:ta,

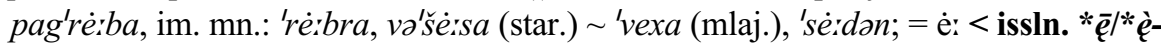
- 'pe:t '5', p'le:s, 'pé:st, 'pé:dan; 'pé:tek, 'ré:p; 1. os. ed. sed. g'lë:dan; s'ré:ča, rod. ed. 'zèita.

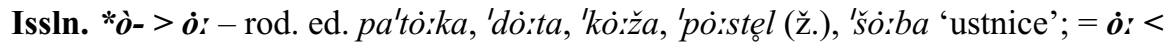

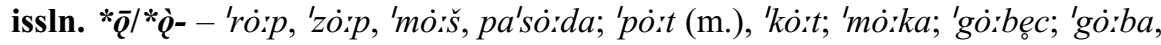
'to: ča.

\subsection{Vokalizacija dolgega slovenskega polglasnika}

Dolgi slovenski polglasnik $*_{\bar{\partial}}<$ issln. $* \bar{\partial} / * j$ - se v dolenjski narečni ploskvi vokalizira v smeri proti $a$ in sovpade z razvojem etimološkega $* a$. To izkazujeta tudi govora Ravnic in Babnega Polja, slednji še z ohranjeno labializacijo.

Babno Polje:

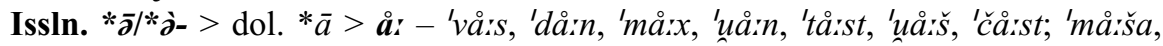
'tå:šča, s'nå:xa, 'sårinne, 'pårsje, 3. os. ed. sed.: f'sårxne 'usahniti', p'remårkne, 'pårxne 'pahniti', 'gå:ne 'ganiti'.

Ravnice:

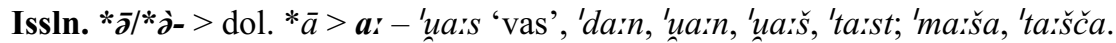

\subsection{Labializacija issln. * $u$}

V govorih Babnega Polja in Ravnic je današnji odraz issln. ${ }^{*} \bar{u} / *^{*} \grave{u}-(>$ jsln. $* \bar{u}>$ dol. $* \bar{u})$ kratki $u$, kar je rezultat mlajšega krajšanja visokih vokalov, tj. etimološkega $u$ (tudi $u<$ issln. ${ }^{*} \overline{\mathrm{o}}$ ) in $i$. Njegovo nekdanjo zaokroženost ${ }^{7}$ lahko dokazujemo z odsotnostjo švapanja, ki je sicer v obravnavanih govorih pred zadnjimi vokali dosledno (Rigler 2001: 129):

Babno Polje: 'luč, 'lukna, 'luna: 'kauo, 'de:ikua.

Ravnice: 'luč, 'lukna: 'kaunu, pua'nina.

7 Tako tudi Pronk (2010: 120), ki piše: »Prvotni *u je postal sprednji * $\ddot{u}$ v zahodnih govorih Gorskega kotarja in v Beli krajini, verjetno pa tudi v vzhodnem goranskem [govoru].« 


\section{$5 \quad$ Mlajše jezikovne spremembe}

Narečja znotraj dolenjske narečne ploskve se nadalje delijo glede na novejše jezikovne inovacije. Izguba tonemskih nasprotij in prisotnost mlajših naglasnih umikov kostelske govore ločuje od dolenjskega narečja. ${ }^{8}$ Hkrati pa ga prav omenjeno povezuje $\mathrm{z}$ belokranjskimi narečji, ki prav tako poznajo izgubo tonemskih nasprotij in mlajše naglasne umike. Mlajša naglasna sprememba, tj. umik naglasa z zadnjega dolgega odprtega in zaprtega zloga, splošen zvočni vtis in razvoj zapornika $g \mathrm{v}$ pripornik ločujejo kostelsko narečje od notranjskega, ki je sinhrono gledano del primorske narečne skupine. Kljub temu pa prav nekatere mlajše naglasne spremembe tudi povezujejo obe narečji, in sicer izguba tonemskih nasprotij, umik na prednaglasno nadkračino in umik naglasa s končnega kratkega zaprtega zloga.

Mlajše samoglasniške in soglasniške spremembe služijo za ločevanje znotraj kostelskega narečja samega in ga delijo na njegov SZ in JV del. Kostelsko narečje tako določajo (Šekli 2009: 307; Gostenčnik 2013) tile pojavi.

\subsection{Mlajše naglasne spremembe}

Vsi govori kostelskega narečja so izgubili tonemska nasprotja in kažejo izrazito tendenco umika naglasa z zadnjega zloga, in sicer na predhodni nadkratki (umik na prednaglasno nadkračino), kratki (umik naglasa z zadnjega kratkega zaprtega zloga na predhodni zlog) in dolgi samoglasnik (umik naglasa z zadnjega dolgega odprtega in zaprtega zloga na predhodni zlog).

\subsubsection{Umik na prednaglasno nadkračino}

Babno Polje: s'kodọn, 'mogua, s'tọza.

Ravnice: s'kędę, s'tęber, 'peku 'pekel', s'teza, 'megua, 'deska, rod. ed.: 'pesa 'pes', 'děšzia.

5.1.2 Umik naglasa $z$ zadnjega dolgega na predhodni zlog (odraz tonema psl. starega dolgega cirkumfleksa in novega dolgega akuta) ${ }^{9}$

Babno Polje (primeri za tercirani premik cirkumfleksa so navedeni v razdelku 3.2): 'mexor 'mehur', 'zidar, 'pastẹr 'pastir', 'kavač, k'uabuk, 'kamar 'komar', 'čudak $\sim\left(c^{\prime}{ }^{\prime} d a ̊ k k\right), 3$. os. ed. sed.: 'bali 'boleti', 'tapi 'topiti', 'gari 'goreti', 'rasi 'rositi',

8 Severozahodni govori kostelskega narečja se od dolenjskega narečja dodatno razlikujejo s krajšanjem visokih vokalov $i$ in $u$ ter prisotnostjo švapanja.

9 Tine Logar je v opisu belokranjskih govorov (1996: 80) uporabljal izraz »umik dolgega akuta z zadnjega zloga«, vendar pa je bil tam govor le o odrazu tonema praslovanskega novega dolgega akuta. Izraz »umik naglasa $\mathrm{z}$ zadnjega dolgega na predhodni zlog« torej zajema tako Logarjev »umik dolgega akuta $\mathrm{z}$ zadnjega zloga « kot tudi terciarni premik cirkumfleksa. Kot je predvideval že Logar za belokranjske govore (Logar 1996: 207), sta oba umika verjetno istočasna, saj so refleksi enaki. 
- $\quad z^{\prime}$ gani 'zvoniti', 'uavi 'loviti', 'ževi 'živeti', 'tọpi 'trpeti', del. na -l m.: 'radiu 'rodi퍼 ti', 'dabiu 'dobiti', 'anaist a'nå:ist '11'.

N Ravnice (primeri za tercirani premik cirkumfleksa so navedeni v razdelku 3.2):

- $\quad$ 'zidar, 'pastir, gas'padar, 'mexur, k'uobuk, 'kauač 'kovač', s'ramak, 1. os. ed. sed.: se 'patin 'potiti se', s'tajin 'stati', 3. os. ed. sed. $z$ 'gani 'zvoniti', del. na -l m.: 'radiu 'roditi', 'papiu 'popiti'.

\subsubsection{Umik naglasa $\mathrm{z}$ zadnjega kratkega zaprtega zloga na predhodni zlog}

Diahrono gledano je to psl. tonem tipa starega dolgega akuta in tipa novega kratkega akuta na zadnjem zaprtem zlogu, ki sta po krajšavi starega dolgega akuta sovpadla in se dalje v internem slovenskem razvoju razvijala enako, tj. issln. kratkoakutirani zlog. V issln. kratkoakutiranem zadnjem zaprtem zlogu ni prišlo do podaljšave, temveč do metatonije kratkega akuta v kratki cirkumfleks. Naglasni umik je znan vsem govorom kostelskega narečja in sosednjemu notranjskemu narečju.

Babno Polje: 'cẹgan 'cigan', prid. m. 'vessok, 'žẹan; prid. m. g'lẹbok (po švapanju) 'vẹbak' globok', m'uatẹc 'mlatič', prid. m. 'kasmat 'kosmat', 'atrak 'otrok', 'madros 'modras', 'patpuat 'podplat', 'abras 'obraz', 'abut 'obut', prid. m. 'šorak 'širok', 'morlẹč 'mrlič'.

Ravnice: 'cegan 'cigan', 'uabras 'obraz', 'uatrak 'otrok'.

\subsection{Mlajše samoglasniške spremembe}

Med mlajše samoglasniške spremembe prištevamo krajšanje visokih vokalov (SZ kostel. $i<$ issln. $*_{i} / *_{i}$ - in SZ kostel. $u<$ iss $\ln .{ }^{*} \bar{u} / *^{*} \grave{u}_{-} / *^{*} \overline{)}$ ) in njihov sovpad s kratkimi vokali. To je (poleg nekaterih soglasniških sprememb) tudi izrazita ločnica med SZ in JV kostelskimi govori.

Babno Polje:

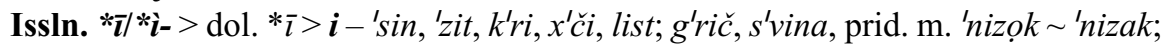
'vinu, 'lice, 'zima, b'lize 'blizu'; b'rinje, 1. os. ed. sed.: 'pišen 'pisati', 'vidẹn 'videti'; 'niva, 'žila, rod. ed. 'miši 'miša, 'lipa, 'riba, im. mn. 'tiči 'ptiči', prid. ž. 'sita.

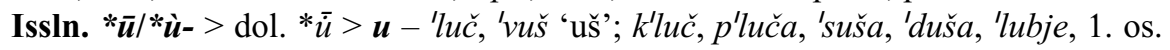
ed. sed. 'lupẹn 'lupiti'; 'vusta; 'lukna, x'ruška; 'jutru, 'muxa, 'bukva 'bukev', k'luka, 'luža, rod. ed.: k'ruxa, 'kupa.

Issln. ${ }^{*} \overline{\boldsymbol{o}}>$ dol. $* \bar{u}>\boldsymbol{u}$ (primeri so navedeni v razdelku 4.2).

Ravnice:

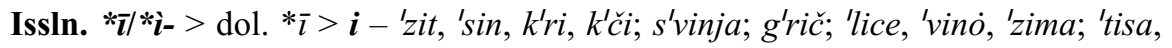
ma'tika, 'misu 'misel'; x'rip, 'riba, 'xiša, '̌̌iua, ka'biua, pua'nina, žlica, rod. ed.: 'niti, 'tiča 'ptič', 'miša, im. mn. 'vile, prid. ž. 'sita.

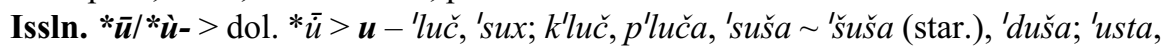
'uizda; 'lukna; 'bukua 'bukev', 'jutru, rod. ed.: 'kupa, k'ruxa.

Issln. ${ }^{*} \overline{\boldsymbol{o}}>$ dol. $* \bar{u}>\boldsymbol{u}$ (primeri so navedeni v razdelku 4.2). 


\subsection{Mlajše soglasniške spremembe}

Soglasniške izofone se v celoti pokrivajo s samoglasniškimi. Za SZ del, kamor glede na mlajše jezikovne spremembe lahko uvrstimo tudi govor Babnega Polja in Ravnic, so značilne naslednje mlajše soglasniške spremembe: ${ }^{10}$ švapanje, depalatalizacija issln. etimološkega in sekundarnega $* l$ v vseh položajih, depalatalizacija issln. * ${ }^{\prime}$ v vzglasju, v položaju za samoglasnikom in soglasnikom, razpad sekundarnega issln. ${ }^{*} n$ na -ịn- in nastop protetičnega glasu $j$.

\subsubsection{Prehod $* \boldsymbol{l}>\underline{u}$ pred zadnjimi samoglasniki(švapanje)}

SZ kostelski govori poznajo prehod $* l>u$ pred zadnjimi vokali (razen pred $u<$ dol. $* \bar{u}<$ issln. $* u$ ).

Babno Polje: s'uåmma, d'uåaka, d'uă:n, 'kauo, 'de:inkua, ab'uå̊řnu, 1. os. ed. sed. 'uå̊žen 'lagati', del. na -l ž. pos'tiúa 'pustiti', prid. ž. dẹ'bi:zúa.

Ravnice: 'uais 'las', 'uarš, m'uai 'mlaj', pua'nina, x'ua:pec, d'ua:n, žéuodoc, 'gaùp 'golob', 'kaun, 'megua, 'žiuna 'žila', del. na -l ž. 'siedua 'sesti'.

\subsubsection{Depalatalizacija issln. * $l^{\prime}$ v vseh položajih}

Babno Polje:

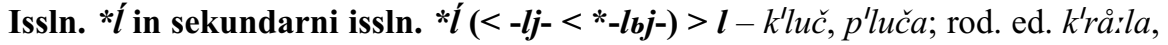
'ziemla, s'ti:'la, 'vu:ala 'volja', ne'derilla, 'pårrkol 'parkelj'; 'zi:əle, 'ụ̂ole 'olje'.

Ravnice:

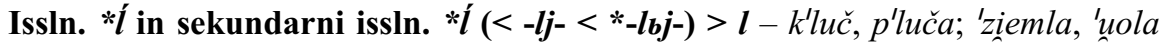
'volja', ne'de:illa, mest. mn. 'žeblax 'žebelj'; 'zè:le.

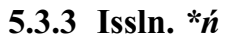

V položaju za samoglasnikom in soglasnikom se $* \dot{n}$ depalatalizira, sekundarni issln. $* \dot{n}(<*-n b j-)$ razpade $\mathrm{v}-i n-$.

Babno Polje:

Issln. *\#向/Vń/Kń > n - 'niva, or. ed. ž 'nim; 'lukna; s'vina, 'uogon 'ogenj', s'kodon. Sekundarni issln. $\dot{n}(<*-n \boldsymbol{b j}-)>\boldsymbol{i n}$ - 'kareini 'korenje', 'kamọnini 'kamenje', z'nåmọini 'znamenje'.

Ravnice:

Issln. *\#ń/Vń/Kń >n - 'niuna; uog'nišče, 'lukna; gaspa'dina, s'kędęn.

Sekundarni issln. $\dot{n}(<*-n b j-)>i n n-p e^{\prime} \check{c} a$ i inje.

${ }^{10}$ Za severozahodni del kostelskega narečja in tako tudi za govora Babnega Polja in Ravnic je značilna tudi disimilacija $z v \rightarrow z g$ v leksemih zvon, zvonec, zvoniti, sicer splošnoslovenski pojav, ki pa je omejen predvsem na narečja, ki poznajo prehod $*_{\bar{o}}>\bar{u}($ ali $\underline{n}$ ) $)$, tj. energično artikulacijo glasu $o$ (Ramovš 1924: 161). 


\section{- 5.3.4 Protetični $j$}

표 Nastop protetičnega $j$ pred vzglasnim $i$ je značilen za vse SZ kostelske govore, ne N pa tudi za JV del govorov. Krajevna govora Babnega Polja in Ravnic tako dosledno $=\quad$ izkazujeta protetični glas $j$.

Babno Polje: 'jẹmi 'ime', 'jẹt 'iti', 1. os. ed. sed. 'jẹščen 'iskati'.

Ravnice: 'jegua 'igla', 'jemi 'ime'.

\section{$6 \quad$ Sklep}

Diahrono-sinhrona primerjava krajevnih govorov Babnega Polja in Ravnic na fonološki ravnini je pokazala, da je mogoče govor Ravnic obravnavati kot del dolenjske narečne ploskve slovenskega jezikovnega sistema. Tako govor Babnega Polja kot govor Ravnic pa ne izkazujeta zgolj skupne lingvogeneze, temveč tudi vzporeden razvoj v mlajšem jezikovnem obdobju, saj so jima skupne tudi mlajše jezikovne spremembe. Na osnovi tega lahko, tako kot govor Babnega Polja, tudi govor Ravnic brez zadržkov uvrstimo med kostelske govore, natančneje kot predstavnika SZ kostelskih govorov. Točka SLA T411 Ravnice je torej utemeljeno ena izmed točk kostelskega narečja v regularni mreži SLA.

\section{Krajšave}

del. = deležnik; dol. = dolenjsko; ed. = ednina; im. = imenovalnik; issln. = izhodiščno splošnoslovensko; jsl. = južnoslovansko; jsln. = južnoslovensko; JV = jugovzhodni; kostel. = kostelsko; $\mathrm{m} .=$ moški spol; mlaj. = mlajše; mn. = množina; nov. $=$ novejše; os. $=$ oseba; prid. $=$ pridevnik; primer. $=$ primernik; psl. = praslovansko; rod. $=$ rodilnik; sed. $=$ sedanjik; sln. = slovensko; star. = starinsko; SZ = severozahodni; vel. = velelnik; zjsl. = zahodnojužnoslovansko; ž. = ženski spol

\section{Viri}

Gostenčnik 2013 = Januška Gostenčnik, Izoglose na stiku slovenskega kostelskega narečja in kajkavskega goranskega narečja: doktorska disertacija, Ljubljana, 2013.

Zapis za SLA za Babno Polje (SLA T279) Albinca Lipovec, 1983, shranjeno v Dialektološki sekciji Inštituta za slovenski jezik Frana Ramovša ZRC SAZU v Ljubljani.

Zapis za SLA za Ravnice (SLA T411) za SLA 1 Karmen Kenda Jež - Jožica Škofic, 2010, shranjeno v Dialektološki sekciji Inštituta za slovenski jezik Frana Ramovša ZRC SAZU v Ljubljani. 
Zapis za SLA za Ravnice (SLA T411) za SLA 2 Karmen Kenda Jež - Januška Gostenčnik, 2010-2014, shranjeno v Dialektološki sekciji Inštituta za slovenski jezik Frana Ramovša ZRC SAZU v Ljubljani.

\section{Literatura}

Belić 1927 = Aleksandar Belić, Kajkavski dijalekt, v: Narodna enciklopedija srpsko-hrvatsko-slovenačka II: I-M, ur. Stanoje Stanojević, Zagreb: Bibliografski zavod, 1927, 222-228.

FO = Fonološki opisi srpskohrvatskih/hrvatskosrpskih, slovenačkih i makedonskih govora obuhvaćenih opšteslovenskim lingvističkim atlasom, ur. Pavle Ivić, Sarajevo: Akademija nauka i umjetnosti Bosne i Hercegovine, 1981.

Gostenčnik 2013a = Januška Gostenčnik, Fonološki opis govora grada Gerovo (prema zapisu Božidara Finke), Slavia Centralis (Maribor) 6 (2013), št. 1, 38-58.

Ivić 1961 = Pavle Ivić, Prilozi poznavanju dijalekatske slike slike zapadne Hrvatske, Godišnjak Filozofskog fakulteta u Novom Sadu VI (1961), 191-212.

Ivšić 1936 = Stjepan Ivšić, Jezik Hrvata kajkavaca, Ljetopis JAZU (Zagreb) 48 (1936), 47-88.

Logar 1996 = Tine Logar, Dialektološke in jezikovnozgodovinske razprave, ur. Karmen Kenda-Jež, Ljubljana: Založba ZRC, ZRC SAZU, 1996.

Lončarić 1982 = Mijo Lončarić, Prilog podjeli kajkavskog narječja, Hrvatski dijalektološki zbornik (Zagreb) 6 (1982), 237-246.

Lončarić 1996 = Mijo Lončarić, Kajkavsko narječje, Zagreb: Školska knjiga, 1996.

Malnar 2008 = Slavko Malnar, Rječnik govora čabarskog kraja, Čabar: Matica hrvatska, Ogranak u Čabru, 2008.

Pronk 2010 = Tijmen Pronk, Rani razvoj goranskih govora, Rasprave Instituta za hrvatski jezik i jezikoslovlje (Zagreb) 36 (2010), št. 1, 97-133.

Ramovš 1924 = Fran Ramovš, Historična gramatika slovenskega jezika II: konzonantizem, Ljubljana: Učiteljska tiskarna, 1924.

Ramovš 1931 = Fran Ramovš, Dialektološka karta slovenskega jezika, Ljubljana: Rektorat Univerze kralja Aleksandra I - Univerzitetna tiskarna, 1931.

Ramovš 1935 = Fran Ramovš, Historična gramatika slovenskega jezika VII: dialekti, Ljubljana: Učiteljska tiskarna, 1935.

Rigler 2001 = Jakob Rigler, Zbrani spisi 1: jezikovnozgodovinske in dialektološke razprave, ur. Vera Smole, Ljubljana: Založba ZRC, ZRC SAZU, 2001.

SLA 1.1 = Slovenski lingvistični atlas 1: človek (telo, bolezni, družina) 1: atlas, ur. Jožica Škofic, Ljubljana: Založba ZRC, ZRC SAZU, 2011 (Jezikovni atlasi).

SLA 1.2 = Slovenski lingvistični atlas 1: človek (telo, bolezni, družina) 2: komentarji, ur. Jožica Škofic, Ljubljana: Založba ZRC, ZRC SAZU, 2011 (Jezikovni atlasi). 
Snoj 2009 = Marko Snoj, Slovenski etimološki slovar, Ljubljana: Modrijan, ${ }^{2} 2009$. Šekli 2009 = Matej Šekli, Merila določanja mej med slovenskimi narečji in podnarečji, v: Slovenska narečja med sistemom in rabo, ur. Vera Smole, Ljubljana: Znanstvena založba Filozofske fakultete, 2009 (Obdobja 26: metode in zvrsti), 291-318.

Šekli 2013 = Matej Šekli, Zemljepisnojezikoslovna členitev kajkavščine ter slovensko-kajkavska jezikovna meja, Slovenski jezik - Slovene Linguistic Studies (Ljubljana - Provo, Utah) 9 (2013), 3-53.

\section{A comparison of the local dialects of Babno Polje and Ravnice in the light of older and more recent Slovene language phenomena}

\section{Summary}

This article compares the local dialect of Babno Polje in Slovenia, which is part of the Kostel dialect in the Lower Carniolan dialect group of Slovenian, and that of Ravnice in Croatia's Gorski Kotar region, which Croatian dialectology classifies as a western mountain sub-dialect of the mountain dialect in the Kajkavian dialect group of Croatian. Both local dialects are included in the data-point network of the Slovenski lingvistični atlas (Slovenian Linguistic Atlas, SLA): that of Babno Polje as SLA T279, and that of Ravnice as T411.

It is determined that it is impossible to successfully apply definitive Kajkavian characteristics to the local dialect of Ravnice (the so-called Kajkavian accentual base, merger of the reflexes of western South Slavic * ${ }^{2}$ and $*_{\partial}$, and merger of the reflexes for western South Slavic $* Q$ and $* l)$. Both local dialects are also compared on the basis of genetic criteria; that is, older Slovenian linguistic changes (such as the general Slovenian advancement of the circumflex or the general Slovenian progressive metataxis of the circumflex, the general Slovenian retraction of the accent from the final syllable to a pretonic long vowel, parallel diphthongization of early common Sln. ${ }^{*} \bar{o}$ and early common Sln. ${ }^{*} \bar{e}$, and early lengthening of early common Sln. short acute syllabic nuclei in non-final lexical syllables in western and southern Slovenian dialects). Diachronic comparison of both local dialects at the phonological level points to their shared language genesis, whereby the local dialect of Ravnice is established as belonging to the Lower Carniolan dialect group of the Slovenian linguistic system. On the basis of more recent linguistic phenomena, the local dialect of Ravnice is classified in the northwest part of the Kostel dialect in the Lower Carniolan dialect group. The local dialect of Ravnice has thus become one of the points of the Kostel dialect in the regular SLA network. 